\title{
Sulphide-induced metal precipitation in the mantle edge of Macoma balthica (Bivalvia, Tellinidae) - a means of detoxification
}

\author{
Reinhard Windoffer ${ }^{1, *}$, Andreas Jahn ${ }^{2}$, Frank Meyberg ${ }^{3}$, Jens Krieger ${ }^{1}$, Olav Giere ${ }^{1, * *}$

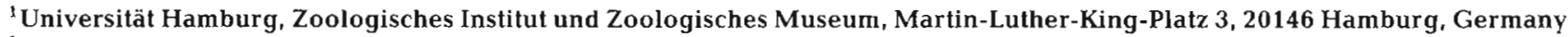 \\ ${ }^{2}$ Institut für Meereskunde an der Universität Kiel, Abteilung Meereszoologie, Düsternbrooker Weg 20, 24105 Kiel, Germany \\ ${ }^{3}$ Universität Hamburg, Institut für Anorganische und Angewandte Chemie, Martin-Luther-King-Platz 6, 20146 Hamburg, Germany
}

\begin{abstract}
The blackening of tissues or mucus of benthic animals from sulphidic environments is a remarkable phenomenon whose ecological interpretation is disputed. In the Baltic clam Macoma balthica the mantle edge turned black after sulphide exposure owing to numerous precipitates in the extracellular matrix underneath the epidermal cells. In the apical parts of these cells, similar precipitates were found, albeit in lower abundance. Elemental analyses showed that copper $\left(214.7 \mu \mathrm{g} \mathrm{g}^{-1} \mathrm{ww}\right.$ [wet weight]) and sulphur $\left(1328.6 \mu \mathrm{g} \mathrm{g}^{-1} \mathrm{ww}\right)$ were the main components, with iron $\left(311.2 \mu \mathrm{g} \mathrm{g}^{-1} \mathrm{ww}\right)$ and zinc $\left(112.7 \mathrm{\mu g} \mathrm{g}^{-1}\right.$ ww) in lower concentration. Apparently, these precipitates become phagocytosed by amoebocytes and concentrated in haemocytic granules. This is interpreted as a pathway of removal from the mantle edge. On the basis of calculated diffusion rates $\left(D_{\mathrm{HS}^{-}}=1.9 \times 10^{-6} \mathrm{~cm}^{2} \mathrm{~s}^{-1}\right)$, there is a sulphide influx of $61 \mathrm{nmol} \mathrm{h}^{-1}$ into the body of $M$. balthica. Even under conservative assumptions, this would lead to the binding of all the copper present in about $30 \mathrm{~min}$. It is concluded that the process of sulphide precipitation can represent a temporarily effective pathway attenuating sulphide toxification.
\end{abstract}

KEY WORDS: Macoma balthica - Baltic Sea - Bivalves - Hydrogen sulphide - Diffusion - Detoxification . Anoxia $\cdot$ Heavy metals - Ultrastructure Elemental analysis

\section{INTRODUCTION}

Various marine species can survive hydrogen sulphide concentrations which are toxic to the vast majority of higher animals (National Research Council 1979). These species have developed several pathways to reduce sulphide concentrations in their tissues and/or use anaerobic pathways substituting the sulphide-blocked aerobic respiration chain (Theede et al. 1969, Theede 1973, Somero et al. 1989, Vismann 1991, Bagarinao 1992, Giere 1992, Grieshaber et al. 1992, Grieshaber \& Völkel 1998).

\footnotetext{
- Present address: Universität Mainz, Anatomisches Institut, Becherweg 13, 55099 Mainz, Germany

-Addressee for correspondence.

E-mail: olav.giere@zoologie.uni-hamburg.de
}

A remarkable phenomenon in some of these species is the formation of sulphide precipitates, leading to the blackening of tissues or extracellular material. In oligochaetes (Giere et al. 1988, Dubilier et al. 1995), nematodes (Nuß 1984, Nuß \& Trimkowski 1984, Nicholas et al. 1987, Thiermann et al. 1994), molluscs (Levitt \& Arp 1991, Oeschger \& Pedersen 1994), priapulids (Oeschger \& Janssen 1991, Janssen \& Oeschger 1992) and echinoderms (Buchanan et al. 1980), these precipitates can be found in extracellular mucus, the epidermis or the intestinal wall. In most cases, iron was detected as the main metallic constituent.

It has been speculated that these precipitates or the blackening of tissues represent a detoxification mechanism of sulphide (Buchanan et al 1980, Oeschger \& Janssen 1991, Vismann 1991, Oeschger \& Pedersen 1994). Formation of non-toxic stable sulphur-metal compounds had been supposed to be a means of de- 
toxification of hydrogen sulphide. Metal precipitates would act as a temporary 'sulphide-trap' at the animalenvironment interface, keeping sulphide concentrations in the internal tissues low. However, calculations of sulphide influx rates rendered the efficiency of this reaction as a detoxification mechanism doubtful (Powell 1989, Dubilier et al. 1995). Furthermore, an effective export mechanism of the precipitates, indispensable to the prevention of an overload of precipitates in the tissues (Powell 1989, Somero et al. 1989), has not been found. Therefore, the significance of the sulphide-induced blackening still remains unclear.

We studied this phenomenon in the Baltic clam

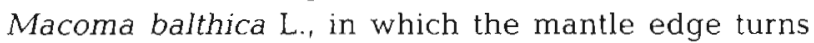
black after sulphide exposure (Windoffer \& Jahn 1994, 1995). This bivalve, a characteristic species of the Baltic Sea, is abundant in marine and estuarine soft bottom habitats of the northern hemisphere (Beukema \& Meehan 1985, Meehan 1985, Väinölä \& Varvio 1989. Günther 1991, Bonsdorff et al. 1995). Living at a sediment depth of 3 to $8 \mathrm{~cm}$, where anoxic conditions frequently occur, the clams often become exposed to high concentrations of hydrogen sulphide. Physiological investigations have shown that $M$. balthica is well adapted to sulphidic conditions (Theede et al. 1995, Jahn \& Theede 1997, Jahn et al. 1997). Clams from sulphidic habitats survived for weeks when experimentally exposed to $100 \mu \mathrm{mol} \mathrm{l}^{-1}$ sulphide under oxic conditions, and for several days under hypoxic conditions. They were able to keep the sulphide concentration in their tissues low by oxidation of penetrated sulphide to non-toxic compounds such as thiosulphate, elemental sulphur or sulphite. When exposed to low sulphide concentrations, this might suffice to prevent the inhibition of cytochrome-c-oxidase (Jahn \& Theede 1997. Jahn et al. 1997).

In this study, we analyse the ultrastructure of specimens taken from sulphidic Baltic Sea habitats or from experimental sulphide incubations in order to investigate morphological aspects and the chemical nature of the precipitates. In addition, we discuss the significance of the blackening and the diffusive processes relevant for sulphide detoxification.

\section{MATERIALS AND METHODS}

Oxic and sulphidic incubations. Specimens of adult Macoma balthica, about $20 \mathrm{~mm}$ in length, were collected from sulphidic sediments off the Island of Hiddensee (Baltic Sea), at a water depth of about $0.5 \mathrm{~m}$. Here, concentrations of sulphide in the pore water of the sediment reach up to $500 \mu \mathrm{mol} \mathrm{l}^{-1}$ (Jahn \& Theede 1997). The specimens were kept for $8 \mathrm{wk}$ in 2 aquaria (20 1), filled with oxic sand or the original sulphidic mud from the habitat. In the oxic aquarium, the sand was covered with $0.5 \mathrm{~cm}$ of sediment from the original habitat to supply the clams with detrital food. The water in both aquaria was continuously aerated with an air pump. Weekly measurements of hydrogen sulphide (according to Gilboa-Garber 1971) proved the absence of sulphide in the oxic aquarium, whereas in the sulphidic aquarium sulphide concentrations were 100 to $200 \mu \mathrm{mol} \mathrm{I}^{-1}$. (The term 'sulphide' in this study refers to total sulphide: undissociated $\mathrm{H}_{2} \mathrm{~S}$, dissociated $\mathrm{HS}^{-}$, and $\mathrm{S}^{2-}$.)

Electron microscopy and qualitative elemental analysis. Specimens of Macoma balthica were collected from sulphidic sediments in the field (location described above). The clams were dissected in fixative, and small tissue blocks of the mantle edge excised. The tissues were fixed in modified Trump's fixative (McDowell 1978: 4\% paraformaldehyde, 3\% glutardialdehyde and $5 \%$ sucrose in $0.1 \mathrm{M}$ cacodylate buffer). After $24 \mathrm{~h}$, the samples were washed in cacodylate buffer containing 5\% sucrose. Tissue blocks were postfixed in $1 \% \mathrm{OsO}_{4}$ (in $0.1 \mathrm{M}$ cacodylate buffer with $5 \%$ sucrose) for $1 \mathrm{~h}$, dehydrated in acetone, and Spurr embedded

In order to reduce the effect of elemental dislocation caused by dehydration, the mantle edge of one specimen was embedded in Nanoplast (Frösch \& Westphal 1989), which avoids complete dehydration of tissues. Tissue samples were fixed in Trump's fixative and then transferred to Nanoplast. Polymerisation was obtained during $6 \mathrm{~d}$ at gradually increased temperatures up to $60^{\circ} \mathrm{C}$.

For conventional transmission electron microscopy (Zeiss EM902), ultrathin sections (70 nm) were stained with uranyl acetate and lead citrate.

For electron energy-loss spectroscopy (EELS) studies, unstained ultrathin sections (30 to $50 \mathrm{~nm}$ ) were used (Egerton 1986). Spectra were recorded in the spectrum mode of the electron microscope using an objective aperture of $90 \mu \mathrm{m}$, a spectrometer aperture of $100 \mu \mathrm{m}$, and a magnification of $85000 \times$ or $140000 \times$. The curves were computer-analysed using the software package Analysis $3.0^{\oplus}$. Spectra were analysed according to Ahn \& Krivanek (1983). Positive signals appear in the spectra as peaks ( $F$, partim) or shoulders $(\mathrm{S}, \mathrm{Cu}, \mathrm{Zn})$. EELS allows for investigation of the elemental composition in single precipitates found in biological tissues. However, it does not represent a quantitative method. Hence, spectra of 'background tissues' have to be compared with spectra from the precipitates to recognise misleading signals such as resin or grid material.

Quantitative elemental analysis. Specimens of $M a-$ coma balthica were dissected and different tissues excised for the following analyses: 3 animals each 
were taken (1) from sulphidic sediments in the field, and from aquaria (see above) kept for 8 wk under (2) oxic and (3) sulphidic conditions. Tissues of 3 individuals each from field and laboratory material were treated with $4 \mathrm{ml} \mathrm{HNO}_{3}$ (Suprapur; Merck) for digestion at $130^{\circ} \mathrm{C}$ under pressure (Würfels \& Jackwerth 1985). Each solution was reduced to $1 \mathrm{ml}$ by evaporation at $110^{\circ} \mathrm{C}$ and finally topped up with distilled water to $20 \mathrm{ml}$. The sulphur concentration in this solution was measured by inductivity-coupled-plasma atomic emission spectroscopy (ICP-AES, Perkin Elmer Plasma II). For calibration, oyster tissue SRM 1566 and a diluted standard solution were used. The recorded values of those elements relevant to this study (bold in Table 1) are far beyond the limits of detection.

\section{RESULTS}

\section{Structural analysis of the dark precipitates}

In freshly collected specimens of Macoma balthica from sulphidic sediments, the mantle edge was distinctly black. The same was found in specimens kept in the laboratory for $8 \mathrm{wk}$ in sulphidic sediment (Fig. 1A). This coloration flanked the mantle edge as a dark stripe (Figs. $1 \mathrm{~B} \& 3 \mathrm{~A}$ ) which extended in diameter from the sensory lobe to the periostracum groove (Fig. 2). In the anterior part of the animal, the stripe was very dark; towards its end in the median part its intensity decreased continuously. Whole-mount preparations of the mantle edge showed that the dark layer consisted of fine precipitates in the matrix of the epidermal cells and larger granules in the underlying haemocytes (Fig. 1C). Clams kept in oxygenated sediment had no or very few small dark spots (Fig. 1D).

Ultrastructurally, the black accumulations in the extracellular matrix (Fig. 3B,C) represented electron-dark precipitates with a diameter from 50 to $250 \mathrm{~nm}$ and a spherical to irregular shape. In deeply blackened specimens the $70 \mathrm{~nm}$ ultrathin section contained up to 100 precipitates $\mu^{-2}$. Most precipitates occurred throughout the basal matrix directly underneath the epidermal cells. In lower abundance, precipitates were also found in the extracellular matrix between the peripheral muscle cells of the mantle edge (Fig. 3C).

Amoeboid cells, characterised by a cytoplasm rich in vacuoles and by several slender branched extensions,
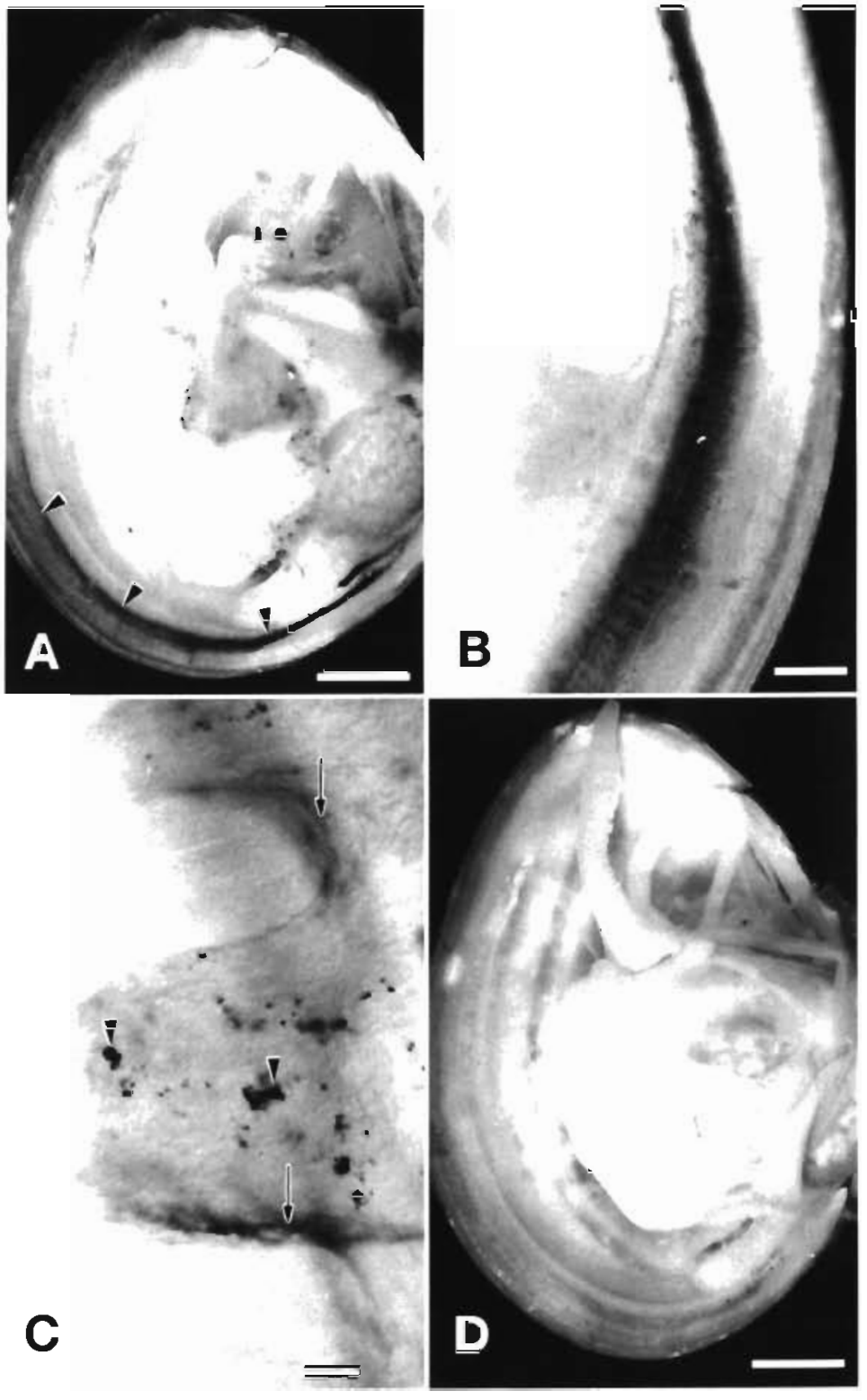

Fig. 1. Macoma balthica. Coloration of mantle edge. Photographs taken from freshly prepared specimens. $(A, B, C)$ Clam kept for 8 wk under sulphidic conditions. (A) Dark coloration clearly visible (arrowheads). Scale bar $=0.25 \mathrm{~cm}$. (B) Dark coloration restricted to small stripe along mantle edge. Scale bar $=0.5 \mathrm{~cm}$. (C) Microscopic whole-mount preparation of mantle edge with sensory lobe. Arrows: a dark layer of precipitates in matrix; arrowheads: granula in haemocytes. Scale bar $=50 \mu \mathrm{m}$. (D) Clam kept for 8 wk under oxic conditions. No coloration visible. Scale bar $=0.25 \mathrm{~cm}$

are considered here to be haemocytes (Figs. 3C \& 4A-D, see Cheng 1981). Their cell body had a maximum diameter of $10 \mu \mathrm{m}$ and their extensions could reach more than $20 \mu \mathrm{m}$ in length. These haemocytes were regularly found in the extracellular matrix underneath the epidermis and between the muscles (Fig. 3C). In lower numbers they were also encountered 


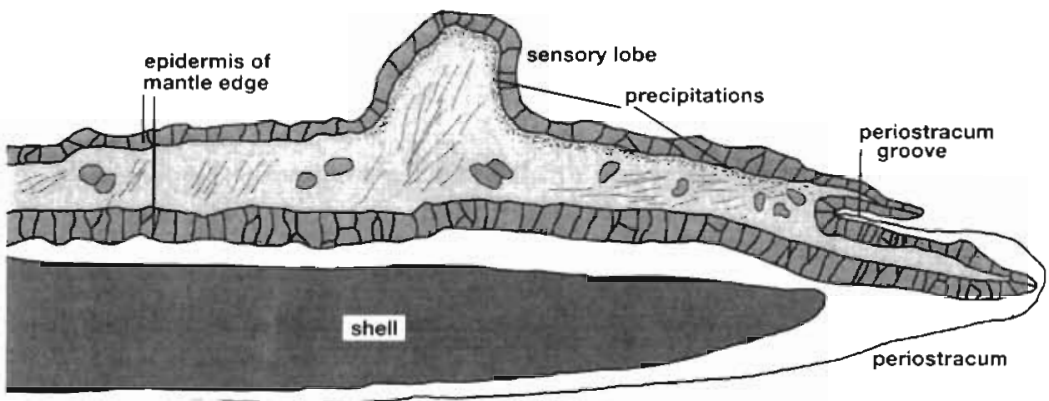

Fig. 2. Macoma balthica. Clam under sulphidic conditions. Schematic drawing of mantle edge. Black coloration appears as thin layer from sensory lobe to periostracum groove

in the entire mantle region. They often contained large electron-dark granules with a diameter of about $10 \mu \mathrm{m}$. These granules obviously represented agglutinations of the extracellular precipitates described above (Figs. 4A-C \& 5A-C). The cytoplasm of the haemocytes was regularly filled with small endocytotic vesicles (Fig. 4C,D), containing inclusions identical to the extracellular precipitates. Inside the haemocytotic cytoplasm these precipitates developed into granules by successive accumulation (Fig. 5A-C). Eventually a single haemocyte could store up to 10 granules.

Another site in the mantle edge harbouring dark precipitates was small vacuoles in the apical parts of the inner epidermal cells. Too small in size and number to yield a visible coloration, these precipitates could only be seen under the electron microscope (Fig. 6A,B)

\section{Qualitative elemental analysis}

Extraceilular matrix - precipitates

EELS analysis showed that the black precipitates in the extracellular matrix of specimens taken from natural sulphidic sediments had sulphur (Fig. 7A) and copper (Fig. 7B) as main components. A peak for iron was not found, nor was the presence of $\mathrm{Zn}$ indicated by a shoulder. Some calcium seemed to also be present, but could hardly be identified against the well-developed $C$ slope (not shown here).
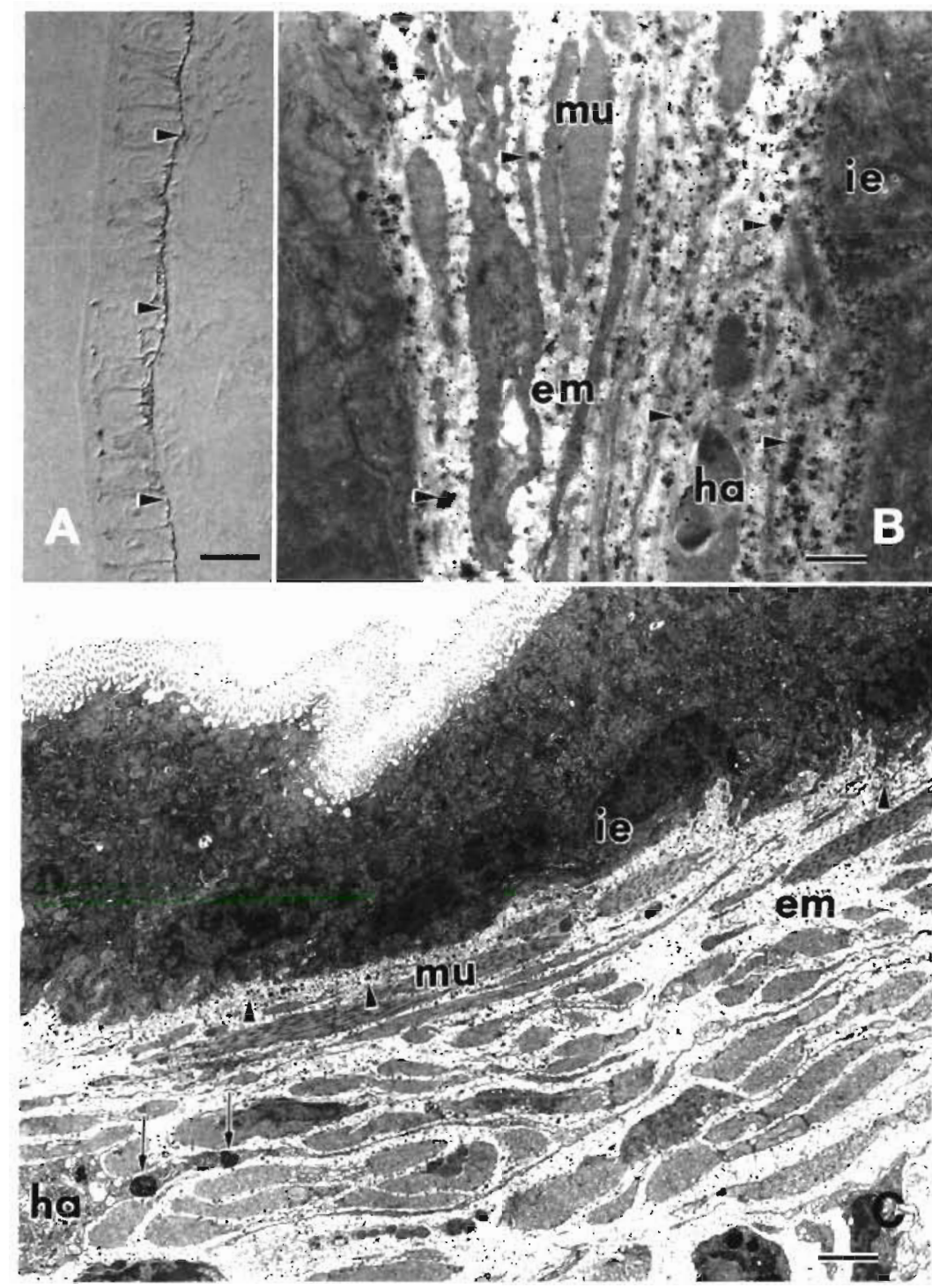

Fig. 3. Macoma balthica. Clam from experimental sulphidic conditions. (A) Light micrograph. Extracellular matrix underneath inner epidermis. Arrowheads: matrix filled up with electron-dark precipitate. Scale bar $=2 \mu \mathrm{m}$. (B) Electron micrograph. Mantle edge with inner epidermis (ie), extracellular matrix (em), muscles (mu), and haemocytes (ha). Arrowheads: electron-dark precipitates in matrix and haemocytes. Scale bar $=0.5 \mu \mathrm{m}$. (C) Electron micrograph. Ultra-thin section of inner epidermis (ie) and adjacent extracellular matrix (em). Arrowheads: precipitates in matrix, especially underneath inner epidermis; arrows: dark granula in haemocytes (ha). Scale bar $=0.5 \mu \mathrm{m}$ 


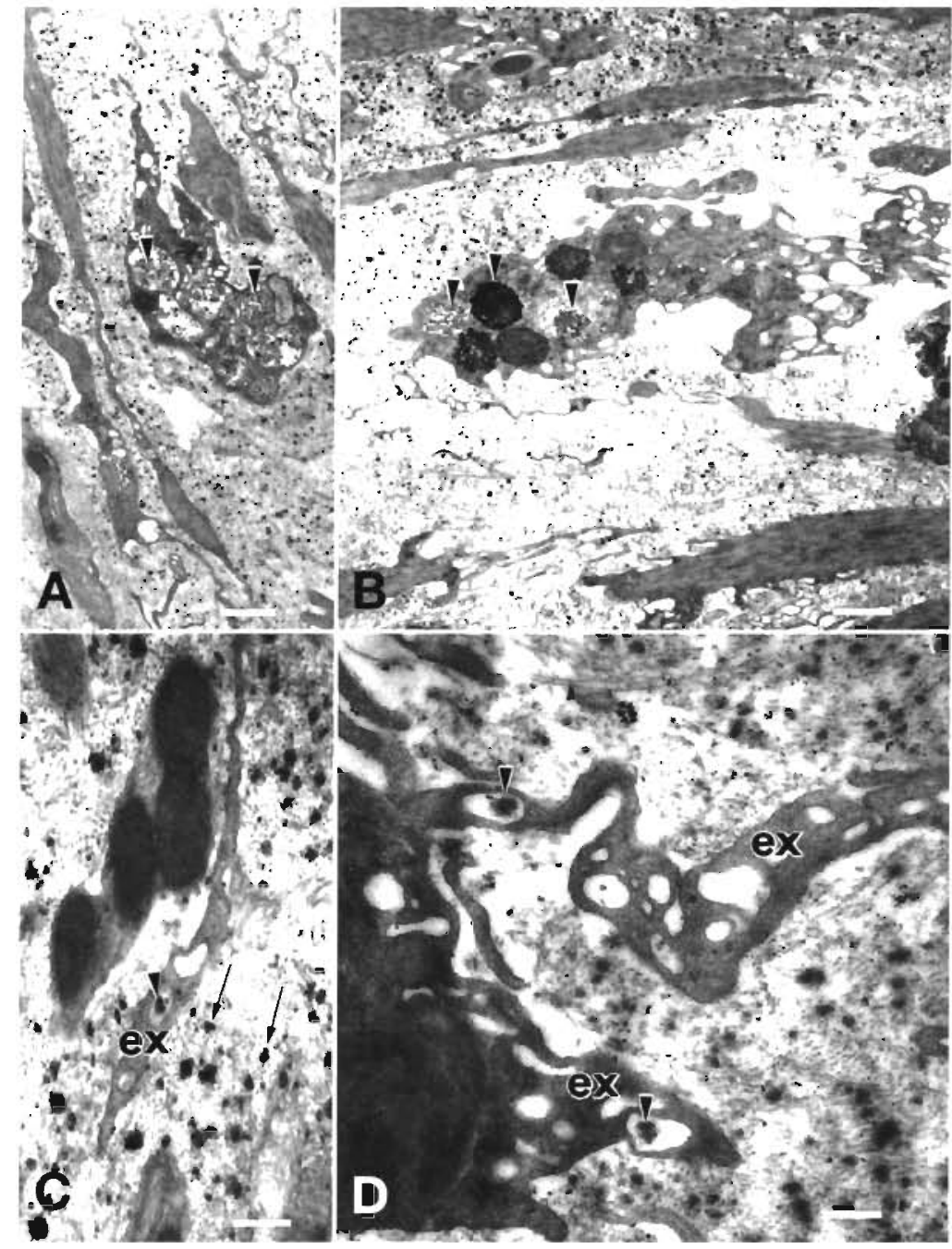

Fig. 4. Macoma balthica. Clam from experimental sulphidic conditions. Electron micrographs. Haemocytes in extracellular matrix underneath inner epithelium of mantle edge. Matrix with many precipitates. (A) Haemocyte with large loosely condensed granules (arrowheads). Scale bar $=1 \mu \mathrm{m}$. (B) Haemocyte with granules in different states of condensation (arrowheads). Scale bar $=1 \mu \mathrm{m}$. (C) Extension (ex) of haemocyte containing similar precipitates (arrowhead) as surrounding matrix (arrows). Scale bar $=0.25 \mu \mathrm{m}$. (D) Extensions (ex) and cell body of haemocyte with vacuoles containing precipitates (arrowheads). Scale bar $=0.25 \mu \mathrm{m}$

while chlorine and phosphorus did not exceed the background level.

\section{Haemocytes}

The aggregated granules in the haemocytes, although all of identical structure, seemed to form 2 different chemical types. While all contained sulphur (Fig. 8A,D), in some of them (Fig. 8A-C) only copper (Fig. 8C) was detectable as a shoulder and a peak, while iron as well as zinc did not show a signal (Fig. 8B, absence of iron; Fig. $8 \mathrm{C}$, no separate shoulder for $\mathrm{Zn}$ ). In contrast, other haemocytic granules (Fig. 8D-F) contained iron (Fig. 8E), but no copper and insignificant zinc (Fig. 8F).

\section{Precipitates in vacuoles of apical epidermal cells}

These granules showed great variability in their elemental components (Fig. 9), but in all of them sulphur and copper were clearly detectable (Fig. 9A,C-E) while iron was never indicated (Fig. 9B). While zinc was clearly detectable in some of them (Fig. 9E), others had only a weak zinc shoulder (Fig. 9C). In some precipitates from other vacuoles (spectrogram not shown here), none of these elements was detected.

\section{Quantitative elemental analysis}

Problems of separating weak EELS signals from background levels suggested that quantitative measurements of the element concentrations using ICP-AES would be appropriate. The foot and mantle edge tissues of clams,

\section{Extracellular matrix - area without precipitates}

In the direct vicinity of the granules and precipitates, the extracellular matrix (and the cytoplasm) was taken as control and comparative background. No clear signals of the above-mentioned spectra were recorded (Fig. 7C,D), indicating the absence of sulphur, iron and copper accumulations. Only zinc seemed to be present (slight elevation of the curve above the baseline in Fig. 7D). Nitrogen and oxygen gave only weak signals, taken directly from sulphidic sediments in the field, showed marked differences in their elemental content (Table 1). In the mantle edge, the concentration of metals such as copper was clearly higher than in the foot (35-fold), so was iron (12-fold) and zinc (4-fold). The sulphur concentration in the mantle edge was about 1.3-fold higher than in the foot.

The same method applied to experimentally sulphide-incubated specimens recorded similar differences between the mantle edge and the foot, with 
Table 1. Macoma balthica. Freshly collected clams from sulphidic habitat. ICP-AES analysis. Elemental concentrations found in foot and mantle edge; important data are shown in bold ( $n=3$; ww: wet weight)

\begin{tabular}{|lcc|}
\hline Element & $\begin{array}{c}\text { Foot } \\
\left(\mu \mathrm{g} \mathrm{g}^{-1} \mathrm{ww}\right)\end{array}$ & $\begin{array}{c}\text { Mantle edge } \\
\left(\mu g \mathrm{~g}^{-1} \mathrm{ww}\right)\end{array}$ \\
\hline $\mathrm{Al}$ & $<23.5$ & 41.2 \\
$\mathrm{~B}$ & $<1.3$ & $<1.3$ \\
$\mathrm{Ba}$ & $<0.3$ & 2.9 \\
$\mathrm{Be}$ & $<0.02$ & $<0.02$ \\
$\mathrm{Ca}$ & $\mathbf{1 4 8 . 1}$ & 360.1 \\
$\mathrm{Cd}$ & $<0.3$ & $<0.3$ \\
$\mathrm{Co}$ & $<0.3$ & $<0.3$ \\
$\mathrm{Cr}$ & $<0.3$ & $<0.3$ \\
$\mathrm{Cu}$ & $\mathbf{6 . 1}$ & 214.7 \\
$\mathrm{Fe}$ & 27.7 & 311.2 \\
$\mathrm{~K}$ & 1125.4 & 910.6 \\
$\mathrm{Mg}$ & 202.6 & 129.5 \\
$\mathrm{Mn}$ & $<0.1$ & $<0.1$ \\
$\mathrm{Na}$ & 1776.5 & 1728.5 \\
$\mathrm{Ni}$ & $<2.1$ & $<2.1$ \\
$\mathrm{P}$ & 938.1 & 749.0 \\
$\mathrm{~Pb}$ & $<6.6$ & $<6.6$ \\
$\mathrm{~S}$ & $\mathbf{9 8 1 . 4}$ & 1328.6 \\
$\mathrm{Sr}$ & 0.9 & 2.2 \\
$\mathrm{Zn}$ & 28.2 & $\mathbf{1 1 2 . 7}$ \\
$\mathrm{F}$ & & \\
\hline
\end{tabular}

clearly higher concentrations of copper and iron, and, to a lesser degree, of sulphur (Fig. 10). Gills, digestive gland and siphon tissue had far lower metal concentrations but a similarly high sulphur content.
Comparing the tissues of specimens from the 2 alternative laboratory treatments, 'oxic' versus 'sulphidic' (Fig. 10), again copper and iron were significantly enriched in the mantle edge of 'sulphidic clams' compared to 'oxic clams'. With regard to sulphur concentrations, again the mantle edge had the highest values, but the sulphidic treatment yielded only a small, albeit significant, enrichment compared to the oxic treatment. In the other tissues analysed, the differences between treatments were not significant.

\section{Quantitative calculation of sulphide precipitation}

Calculations of the binding capacity of copper ions for sulphide in Macoma balthica were made in order to examine the relevance of hydrogen sulphide detoxification by precipitation. After sulphidic incubation of specimens, the concentration of copper in the mantle edge $\left(420 \mathrm{\mu g} \mathrm{g}^{-1} \mathrm{ww}\right.$ [wet weight]) was almost $200 \mu \mathrm{g}$ $\mathrm{g}^{-1} \mathrm{ww}$ higher than in clams from oxic incubation (230 $\mathrm{\mu g} \mathrm{g}^{-1} \mathrm{ww}$, Fig. 10). Under the same incubation conditions, copper values of the mantle edge, compared with those of the foot, showed an even greater difference (>400 $\left.\mathrm{g} \mathrm{g} \mathrm{g}^{-1} \mathrm{ww}\right)$. In specimens taken directly from sulphidic natural habitats, the difference between foot and mantle edge tissue was still about $200 \mu \mathrm{g} \mathrm{g}^{-1} \mathrm{ww}$ of copper, although the absolute concentrations were generally lower (Table 1).

In the following calculation we assume a copper concentration of $200 \mathrm{\mu g} \mathrm{g} \mathrm{g}^{-1} \mathrm{ww}$ as the amount of copper in the mantle edge available for binding sulphur. In adult specimens, a typical mantle edge of $10 \mathrm{mg} w \mathrm{w}$ would then contain $2 \mu \mathrm{g}$, or $32 \mathrm{nmol}$ of copper. Assuming a Cu:S binding ratio of $1: 1$, which under physiological conditions is a most conservative estimate (see 'Discussion'), this amount is capable of binding $32 \mathrm{nmol}$ of sulphide.

Using Fick's first law

$$
\frac{\Delta n}{\Delta t}=-D A \frac{\Delta c}{\Delta x}
$$

we calculated the amount of sulphide $(\Delta n)$, which enters the mantle edge in a given time $(\Delta t)$ and becomes precipitated at an assumed depth of $\Delta x=20 \mu \mathrm{m}$ underneath the epidermal surface. When the shells are opened, the surface of the paired mantle edge exposed to the sediment is assumed to be roughly a rectangle of $A=0.1 \mathrm{~cm} \times 1.5 \mathrm{~cm}=0.15 \mathrm{~cm}^{2}$.

For the next calculation step we used the apparent diffusion coefficient $D$ for
Fig. 5. Macoma balthica. Clam from experimental sulphidic conditions. Electron micrographs. Various stages of increasing condensation of precipitates randomly taken from different haemocytes. Scale bars $=0.25 \mu \mathrm{m}$ 


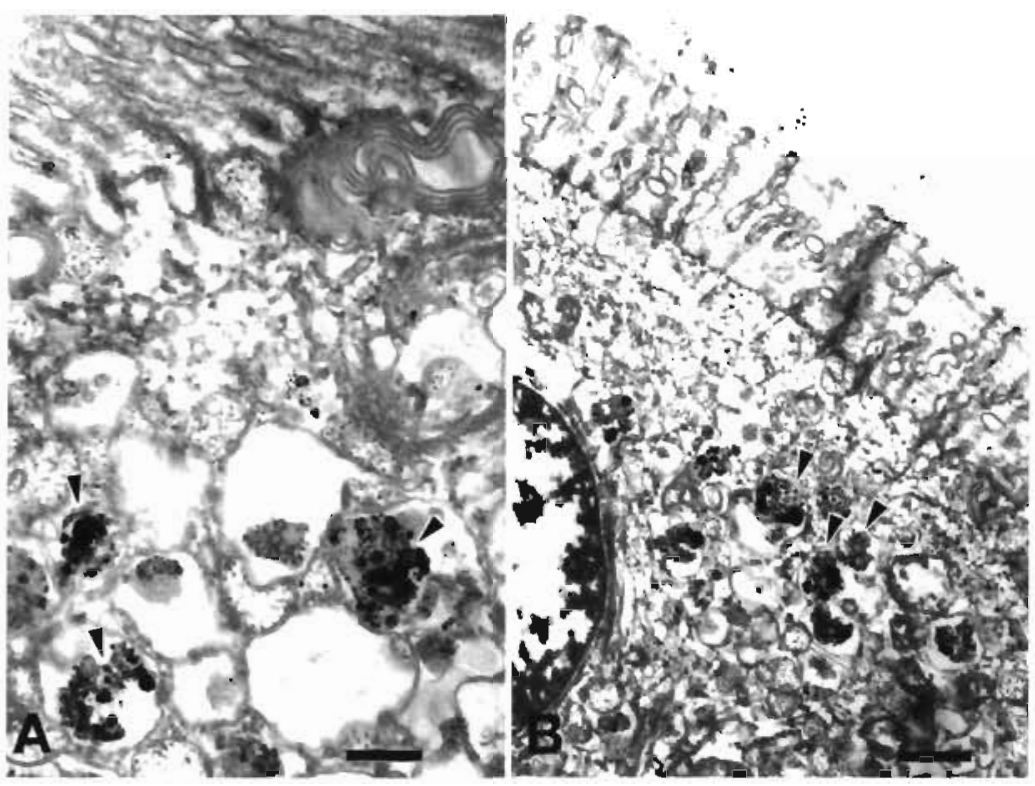

Fig. 6. Macoma balthica. Clam from experimental sulphidic conditions. Precipitates in epidermal cells of inner epidermal layer. Electron micrographs. (A) Precipitates (arrowheads) located in vacuoles of epidermal cells. Scale bar $=0.25 \mu \mathrm{m}$. (B) Accumulation of precipitates (arrowheads) in apical part of epidermal cell. Scale bar $=0.5 \mu \mathrm{m}$

total sulphide of $1.2 \times 10^{-6} \mathrm{~cm}^{2} \mathrm{~s}^{-1}$ which had been assessed for Macoma balthica from Hiddensee (Jahn \& Theede 1997). Given a sulphide gradient between the medium and the tissues of $\Delta c=100 \mathrm{mmol} \mathrm{l}^{-1}$, the sul- phide influx will then be $9 \times 10^{-12} \mathrm{~mol}$ $\mathrm{s}^{-1}$ or $32 \mathrm{nmol} \mathrm{h}^{-1}$. This means that the precipitation capacity of copper will be exhausted after about $1 \mathrm{~h}$. $D$ takes into account protection strategies of the clam such as temporary shell closure (Jahn et al. 1996, 1997). Therefore, the sulphide diffusion rate calculated above is probably a conservative value.

According to Powell (1989), the diffusion coefficient for undissociated $\mathrm{H}_{2} \mathrm{~S}$ in water is about $5 \times 10^{-6} \mathrm{~cm}^{2} \mathrm{~s}^{-1}$. Considering the dissociation of $\mathrm{H}_{2} \mathrm{~S}$, the amount of sulphide entering the body is described according to Fick's first law as:

$\frac{\Delta n}{\Delta t}=$

$-\frac{A}{\Delta x}\left(D_{\mathrm{H}_{2} \mathrm{~S}} \Delta C_{\mathrm{H}_{2} \mathrm{~S}}+D_{\mathrm{HS}^{-}} \Delta C_{\mathrm{HS}^{-}}+D_{\mathrm{S}^{--}} \Delta C_{\mathrm{S}^{--}}\right)$

At a physiological $\mathrm{pH}$, the concentration of $\mathrm{S}^{2-}$ can be neglected $\left(c_{S} \rightarrow 0\right)$. The concentrations of $\mathrm{H}_{2} \mathrm{~S}\left(c_{\mathrm{H}_{2} \mathrm{~S}}\right)$ and $\mathrm{HS}^{-}\left(\mathrm{CHS}^{-}\right)$ can be calculated according to Goldhaber \& Kaplan (1975) from the relationship between the proton concentration $\mathrm{C}_{\mathrm{H}^{+}}$and the total sulphide concentration $C_{T}$ using the first dissociation constant $K_{1}$ $\left(=8.9 \times 10^{-8} \mathrm{~mol} \mathrm{l}^{-1}\right.$ at $10^{\circ} \mathrm{C}$ and a salinity of $9 \%$ ) :
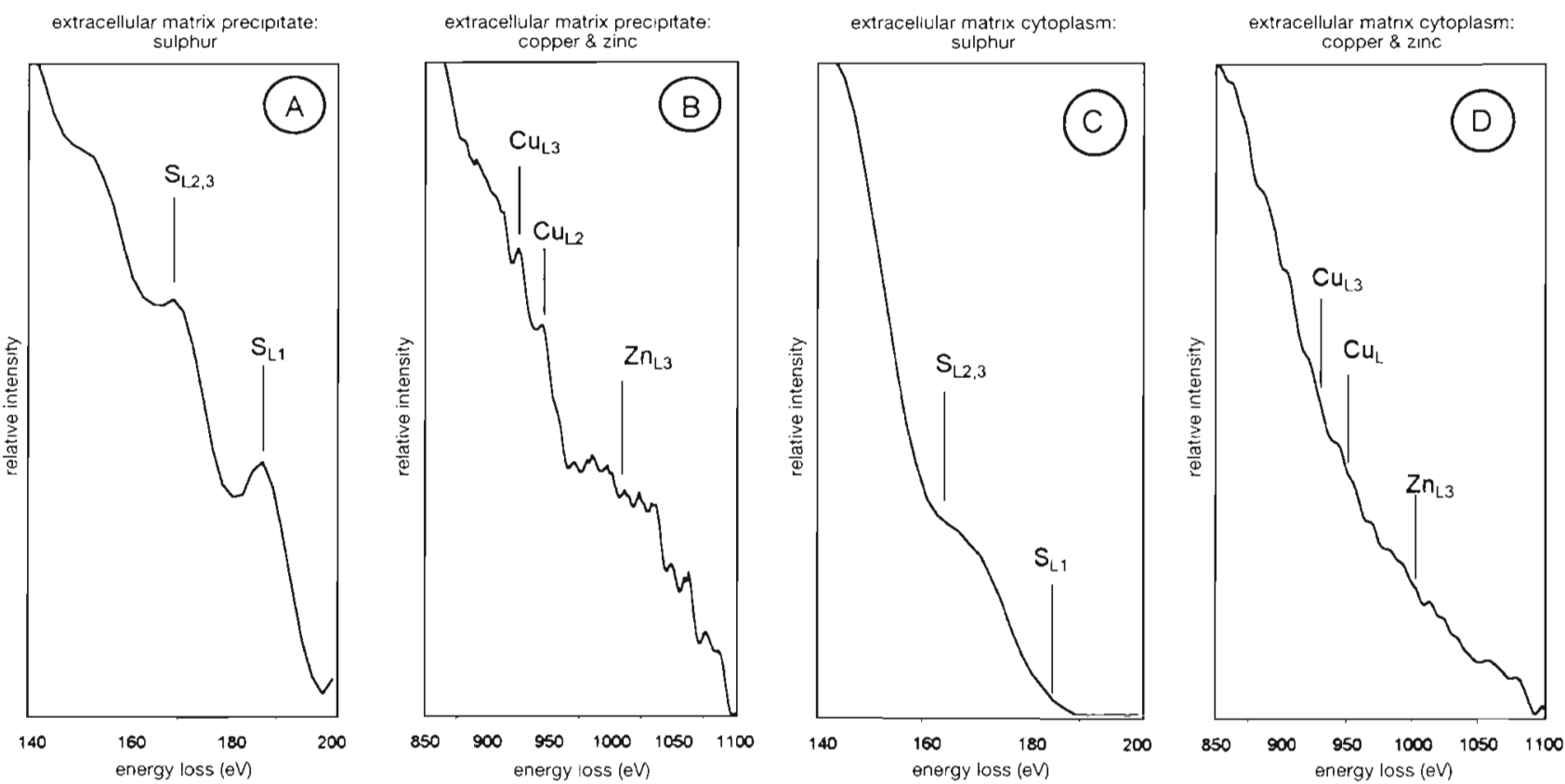

Fig. 7. Macoma balthica. Freshly collected clams from sulphidic habitat. EELS spectra from extracellular matrix. (A,B) Spectra from precipitates. Clear signals for sulphur (A) and copper (B) can be seen; peaks of iron (not shown) and zinc (D) are not discernible from background. (C,D) Spectra from area without precipitates (controls). Signals from sulphur, iron and copper are absent or not discernible from background 

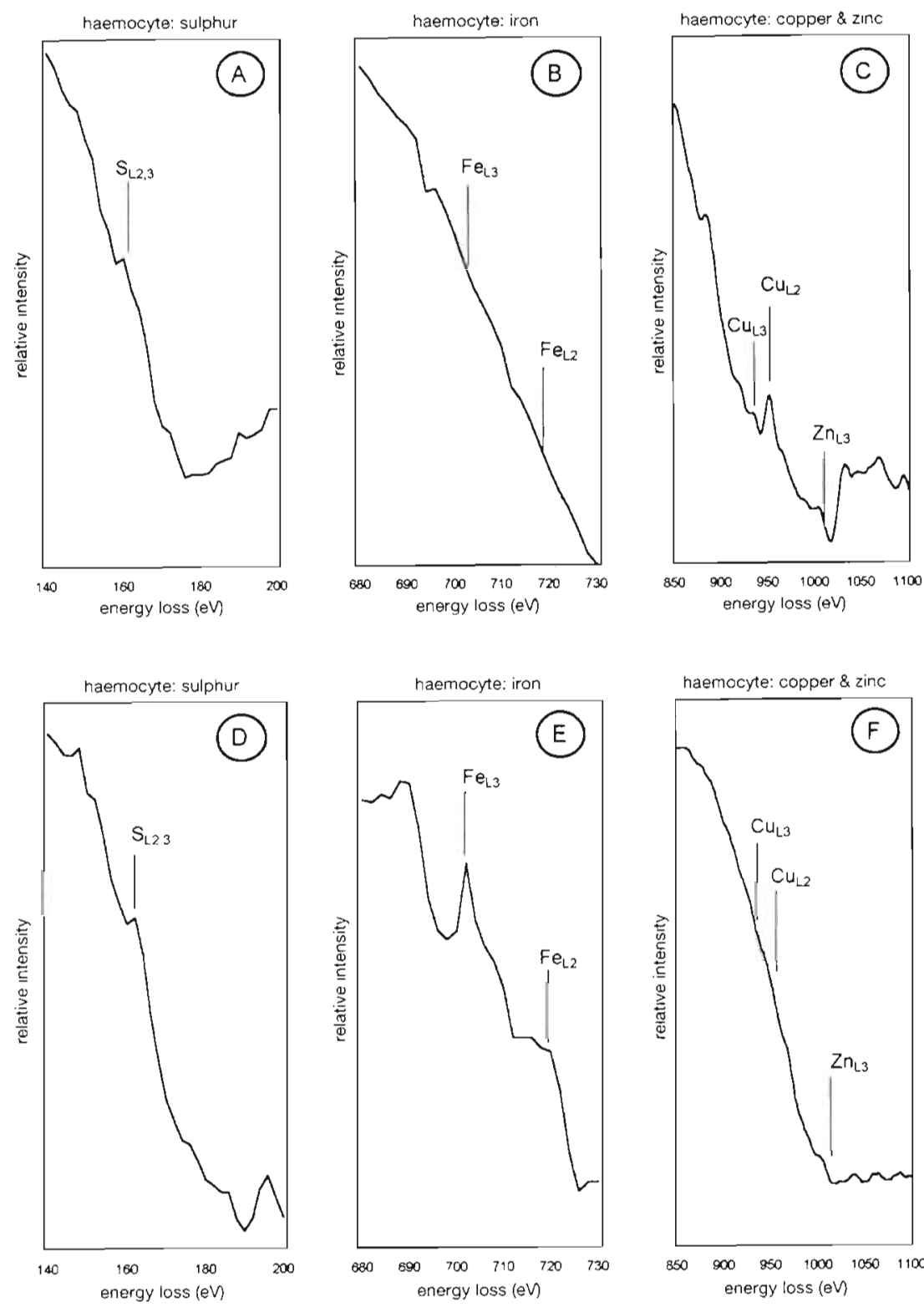

$$
\begin{gathered}
K_{1}=\frac{C_{\mathrm{H}} \cdot C_{\mathrm{HS}^{-}}}{C_{\mathrm{H}_{2} \mathrm{~S}}} \\
C_{\mathrm{HS}^{-}}=C_{\mathrm{T}}-C_{\mathrm{H}_{2} \mathrm{~S}}
\end{gathered}
$$

thus

$$
c_{\mathrm{H}_{2} \mathrm{~S}}=\frac{c_{\mathrm{H}^{*}} c_{\mathrm{T}}}{K_{1}+c_{\mathrm{H}^{-}}}
$$

At a total sulphide concentration of $c_{\mathrm{T}}=100 \mu \mathrm{mol} \mathrm{l^{-1 }}$ and a pH of 8.0, Eqs. (4) \& (5) will lead to $C_{\mathrm{H}_{2} \mathrm{~S}}=10 \mu \mathrm{mol}$ $\mathrm{I}^{-1}$ and $C_{\mathrm{HS}}=90 \mu \mathrm{mol} \mathrm{l}^{-1}$.

The diffusion coefficient of $\mathrm{HS}^{-}\left(D_{\mathrm{HS}^{-}}\right)$is unknown Julian \& Arp (1992) have estimated the permeability of $\mathrm{HS}^{-}$in the body wall of Urechis caupo to be 0.371 times the permeability of $\mathrm{H}_{2} \mathrm{~S}$. Under this assumption, $D_{\mathrm{HS}^{-}}$ is about $1.9 \times 10^{-6} \mathrm{~cm}^{2} \mathrm{~s}^{-1}$. Inserting these values into
Fig. 8. Macoma balthica. Freshly collected clams from sulphidic habitat. (A-C) EELS spectra from typical condensed granulum in haemocyte. Shoulder of sulphur (A) and peak of copper (C) are clearly detectable; peaks of iron (B) and zinc (C) are not discernible from background. (D-F) EELS spectra from other condensed granulum in haemocyte different from that depicted in A-C. High peak of iron (E) and peak of sulphur (D) can be seen; copper and zinc $(F)$ are not detectable

Eq. (2), a sulphide influx in Macoma balthica of $1.7 \times 10^{-11} \mathrm{~mol} \mathrm{~s}^{-1}$ or $61 \mathrm{nmol} \mathrm{h}^{-1}$, can be calculated at an environmental sulphide concentra-

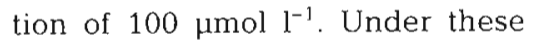
conditions, the $32 \mathrm{nmol}$ of copper assumed above to be present will be completely used up in just $30 \mathrm{~min}$ in the binding of penetrating sulphide.

The above calculations were made assuming a $\mathrm{pH}$ of 8.0. However, in sulphidic sediments with a $\mathrm{pH}$ probably close to 7.0 , the sulphide diffusion will increase to $93 \mathrm{nmol} \mathrm{h}^{-1}$, leading to exhaustion of the copper stored in the mantle edge within only about $20 \mathrm{~min}$.

\section{DISCUSSION}

In the Baltic clam Macoma balthica, the blackening of the basal layer of the mantle edge is caused by electron-dark precipitates. This could be shown by light and electron microscopical observations. EELS recorded accumulations of copper, iron, zinc and sulphur in these granular precipitates. In most cases, these represented clearly elevated metal concentrations in comparison to the background data from surrounding tissues. Also, ICP-AES from specimens collected in the field and in sulphide-treated tanks measured elevated, rather variable concentrations of copper, iron, zinc, and sulphur in the mantle edge, but not in the foot tissue, where precipitates were absent (Table 1, Fig. 10). These data not only underline a differentiated accumulation of metals in the various organs, they also indicate the variability of metal accumulation, especially of copper, in the mantle edge of $M$. balthica as stated by Cain \& Luoma (1986) and Bordin et al. (1992). 
vacuole-bound precipitates in apical region: sulphur

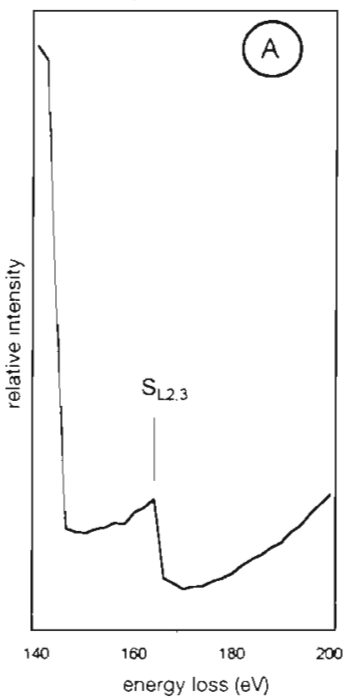

vacuole-bound precipitates in apıca

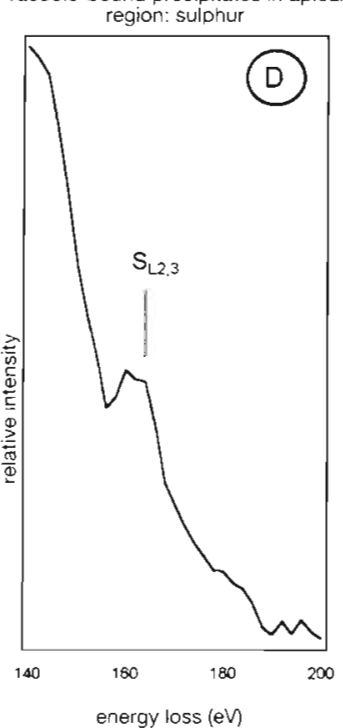

vacuole-bound precipttates in apical region: iron

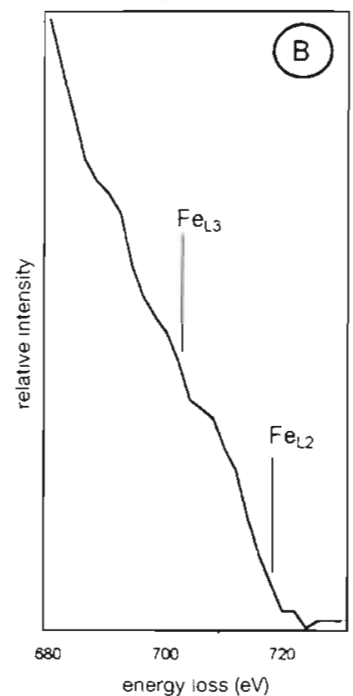

vacuole-bound precipitates in apıcal

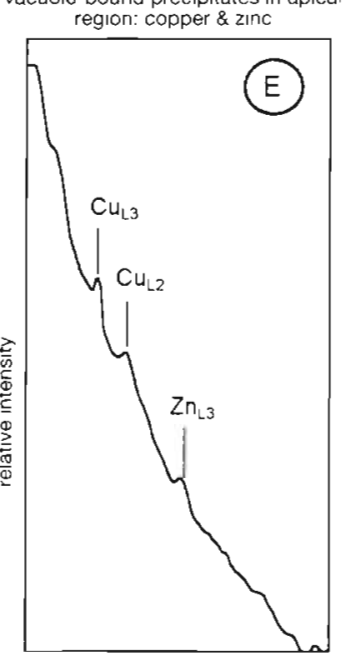

$\begin{array}{llllll}870 & 910 & 950 & 990 & 1030 & 1070\end{array}$

energy loss (ev) vacuole-bound precipitates in apical region: copper \& zinc

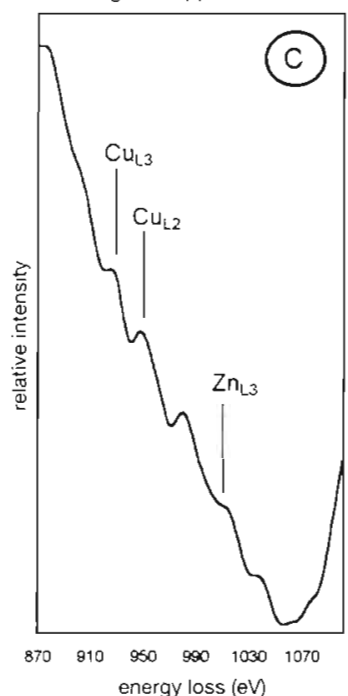

Fig. 9. Macoma balthica. EELS spectra from electron-dense vacuolebound precipitates from apical region of inner epidermal cells. (A-C) Precipitate containing sulphur (A), copper and zinc (C), but no iron (B). (D-E) Another precipitate containing sulphur (D), copper and zinc (F). Again, iron peak (not shown) is not discernible from background

condensed granules of haemocytes, albeit not together with sulphur. The origin of the granules remained uncertain. Also zinc, together with sulphur, has been found, although only occasionally, in some of the vacuoles in the epidermal cells. Therefore, for the Baltic clam, iron and zinc are probably of minor relevance whereas copper seems to be the most important metallic element precipitating sulphur in the mantle edge. The high copper concentrations in the tissues of Macoma balthica recorded here are in contrast to the low bioavailability of copper ions in sulphidic waters regarding the low solubility product of copper sulphides. It is assumed that soluble copper is incorporated into the tissues during oxic phases with the absence of hydrogen sulphide. In the Baltic Sea, frequent and irregular changes of oxic and sulphidic conditions are a characteristic feature (Revsbech et al. 1983, Vopel et al. 1996).

The position of the precipitates and the elemental composition of the corresponding sites was identical in Spurr and Nanoplast sections. This shows that the distribution of elements, measured in the Macoma balthica specimens, was not dislocated and represents very probably their in vivo distribution.

There are various reports on metal precipitates occurring in tissues from benthos living in sulphidic environments. Metal precipitates were found in intestinal

The chemical binding form of metal and sulphur cannot be evidenced by these analytical methods. Their coinciding presence in the granules suggests, however, that copper and sulphur might occur either in an inorganic form (e.g. CuS or $\mathrm{Cu}_{2} \mathrm{~S}$ ) or bound to an organic matrix. The $1: 1$ binding ratio assumed above would be clearly smaller if sulphide was bound as copper polysulphides. This would result in a markedly longer period of effective protection against the penetrating toxic sulphide. Therefore, the value of $30 \mathrm{~min}$ given above is rather conservative.

Unlike the situation for copper, iron precipitates were not formed and stored in the matrix, but in the connective tissues of spatangoid echinoderms (Buchanan et al. 1980) and interpreted as a means to immobilise and detoxify sulphide which was produced by gut bacteria. Also, the intramuscular electron-dark inclusions in Tobrilus gracilis (Nematoda) were believed to participate in sulphide detoxification ( $N u ß$ 1984, Nuß \& Trimkowski 1984). In a detailed comparative study of specimens from oxic and sulphidic sediments, however, these inclusions occurred also in specimens under merely oxic conditions $(O$. Giere unpubl. data), which would question their nature as sulphide detoxicants. Iron- and sulphur-containing granules have been described in the gut of the nematode 

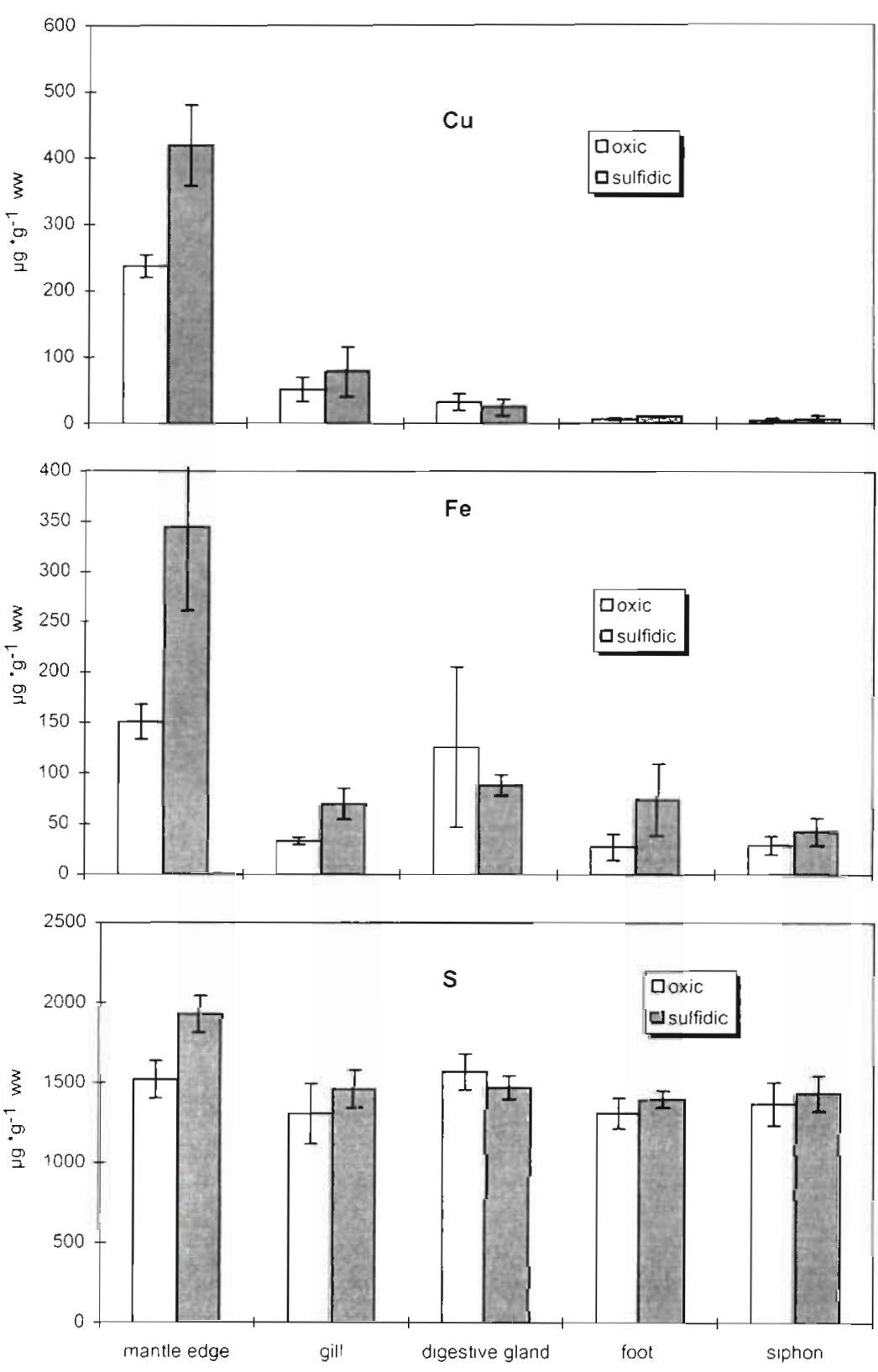

Fig. 10. Macoma balthica. ICP-AES analysis. Copper, iron, and sulphur concentrations found in different tissues after oxic and sulphidıc exposure for $8 \mathrm{wk}$

$(n=3)$; vertical bars indicate standard deviation, $95 \%$ confidence intervals species, $M$. nasuta, as well as that of the local Pacific $M$. balthica population showed, after sulphidic incubation, a dark coloration which was acid-soluble and disappeared after a few hours of oxic exposure. This blackening was based on an extracellular pigmentation and thus was different from that shown here for the Baltic Sea population of $M$. balthica, where the precipitates were intracellular. The dark coloration reported by Levitt \& Arp (1991) in the mantle edge of $M$. nasuta seems comparable to that of $M$. balthica from the Baltic Sea, but was not discussed further. Likewise, in the clam Scrobicularia plana, a dark coloration of the mantle edge was found after sulphide exposure (Oeschger \& Pedersen 1994).

In most of these reports on sulphide precipitates, a relevance for sulphide detoxification has been assumed without further scrutiny. However, Powell (1989) calculated that the microscopically small meiofauna, for physical reasons, cannot guard from sulphide influx into the innermost tissues. On the basis of Powell's results, Dubilier et al. (1995) proved even for the macrobenthic sulphide-tolerant oligochaete Tubificoides benedii that the black mucus coat rich in precipitates of iron sulphide (Giere et al. 1988) could hardly represent an effective shield against sulphide poisoning considering the rapid $\mathrm{H}_{2} \mathrm{~S}$ diffusion. Also, the frequent alterations of mitochondrial ultrastructure, mostly reported as sulphide-induced, need re-examination and probably a new interpretation, since quantitative evaluation of $T$. benedii tissues did not verify the intuitive conclusions drawn from qualitative inspection (Dubilier et al. 1997).

Oncholaimus campylocercoides from shallow-water hydrothermal vents (Thiermann et al. 1994) and in various nematodes from sulphidic mud (Nicholas et al. 1987). In O. campylocercoides, Thiermann (1998) could even experimentally induce the reversible formation of the inclusions after sulphide exposure.

Levitt \& Arp (1991) investigated the sulphide tolerance in 2 Macoma species from Monterey Bay, California. The periostracum of the more sulphide-tolerant
Combining the histological and chemical results with the calculations on sulphide diffusion one can realistically assess the ecological situation of Macoma balthica in its sulphidic environment. These considerations on the protective effectivity of copper are based on 2 realistic assumptions: (1) in nature the increase in sulphide concentrations should proceed slowly (within several hours) since the onset of sulphidic conditions will be retained by the gradual consumption of oxy- 
gen and oxidized compounds (Vopel et al. 1996); and (2) the clams react to sulphide exposure by reducing the opening width of the clam shell or even closing their shells completely, which would reduce the diffusion rate of hydrogen sulphide.

Under the initial low-sulphide conditions (e.g. a concentration of $10 \mathrm{\mu mol} \mathrm{l}^{-1}$ ) the copper present in the mantle edge would suffice to protect Macoma balthica from sulphide poisoning for up to $10 \mathrm{~h}$ by binding free hydrogen sulphide as copper sulphides. This period could be used to activate effective physiological detoxification mechanisms such as oxidation to non-toxic thiosulphate (Jahn \& Theede 1997, Jahn et al. 1997).

On the other hand, there are factors which might reduce the capacity of sulphide detoxification by copper. Copper ions are mainly restricted to the mantle edge, and there is no well-developed vascular system which could steadily provide this region with a sufficient supply of free copper. This would explain the slow appearance of the blackening copper precipitates (within days) under sulphidic conditions and its even slower disappearance (about $2 \mathrm{mo}$ ) when returning to oxic conditions. Hence, the turnover rate of the precipitates appears to be low.

If precipitation by metal ions should represent a sustainable detoxification mechanism, the granules have to be continuously removed to prevent an overload in the tissues (Powell 1989, Somero et al. 1989). In Macoma balthica, the abundance of haemocytes in the blackened mantle edge can serve as an indication for an export mechanism of precipitates. The precipitates would become endocytosed by haemocytes and, after concentration in granules, exported out of the body. One common export pathway of granules in bivalves is via the hepatopancreas and the alimentary tract (Stauber 1950, George et al. 1978); another frequently used mechanism, excreting particularly copper precipitates, is via the kidney (Robinson et al. 1985).

We conclude that under low-sulphide conditions, frequently occurring in the shallow reaches of the Baltic shores, for Macoma balthica precipitation of free sulphide by metals (copper) might be an effective, though temporary, pathway of sulphide detoxification. In combination with other, physiological and ecological, detoxification mechanisms (Jahn et al. 1997), this could explain the survival of the $M$. balthica populations, at least of the larger-sized adults, under hydrogen sulphide conditions.

Acknowledgements. This study was funded by the German Bundesministerium für Bildung, Wissenschaft, Forschung und Technologie (BMBF) as part of the joint research programme on sulphide and methane biotopes in the Baltic and North Sea ('DYSMON II': 03F 0123D). Thanks are due to Prof. $H$. Theede, Kiel, for valuable discussions.

\section{LITERATURE CITED}

Ahn CC, Krivanek OL (1983) EELS ATLAS. HREM Facility, Center for Solid State Science, Arizona State University, Tempe, and GATAN, Inc, Warrendale. PA, p 1-90

Bagarinao $T$ (1992) Sulfide as an environmental factor and toxicant: tolerance and adaptations in aquatic organisms. Aquat Toxicol 24:21-62

Beukema JJ, Meehan BW (1985) Latitudinal variation in linear growth and other shell characteristics of Macoma balthica. Mar Biol 90:27-33

Bonsdorff E, Norkko A, Boström C (1995) Recruitment and population maintenance of the bivalve Macoma balthica (L.) - factors affecting settling success and early survival on shallow sandy bottoms. In: Eleftheriou $A$, Ansell AD, Smith CJ (eds) Biology and ecology of shallow coastal waters. Proc 28th Eur Mar Biol Symp, Iraklio, 1993. Olsen \& Olsen, Fredensborg, p 253-260

Bordin G, McCourt J, Rodriguez A (1992) Trace metals in the marine bivalve Macoma balthica in the Westerschelde Estuary (The Netherlands). Part 1: Analysis of total copper, cadmium, zinc and iron concentrations-locational and seasonal variations. Sci Tot Environ 127:255-280

Buchanan JB, Brown BE, Coombs TL, Pirie BJS, Allen JA (1980) The accumulation of ferric iron in the guts of some spatangoid echinoderms. J Mar Biol Assoc UK 60:631-640

Cain DJ, Luoma SN (1986) Effect of seasonally changing tissue weight on trace metal concentrations in the bivalve Macoma balthica in San Francisco Bay. Mar Ecol Prog Ser 28:209-217

Cheng TC (1981) Bivalves. In: Ratcliff NA, Rowley AF (eds) Invertebrate blood cells. Academic Press, New York, p 233-300

Dubilier N, Giere O, Grieshaber MK (1995) Morphological and ecophysiological adaptations of the marine oligochaete Tubificoides benedii to sulfidic sediments. Am Zool 35:163-173

Dubilier N, Windoffer R, Grieshaber MK, Giere O (1997) Ultrastructure and anaerobic metabolism of mitochondria in the marine oligochaete Tubificoides benedii: effects of hypoxia and sulfide. Mar Biol 127:637-645

Egerton RF (1986) Electron energy-loss spectroscopy in the electron microscopy. Plenum Press, New York

Frösch D, Westphal C (1989) Melamine resins and their application in electron microscopy. Electron Microsc Rev 2: $231-255$

George SG, Pirie BJS, Cheyne AR, Coombs TL, Grant PT (1978) Detoxification of metals by marine bivalves: an ultrastructural study of the compartmentation of copper and zinc in the oyster Ostrea edulis. Mar Biol 45:147-156

Giere O (1992) Benthic life in sulfidic zones of the sea-ecological and structural adaptations to a toxic environment. Verh Dtsch Zool Ges 85(2):77-93

Giere O, Rhode B, Dubilier N (1988) Structural peculiarities of the body wall of Tubificoides benedii (Oligochaeta) and possible relations to its life in sulphidic sediments. Zoomorphology 108:29-39

Gilboa-Garber N (1971) Direct spectrophotometric determination of inorganic sulfide in biological materials and other complex mixtures. Anal Biochem 43:129-133

Goldhaber MB, Kaplan IR (1975) Apparent dissociation constants of hydrogen sulfide in chloride solutions. Mar Chem 3:83-104

Grieshaber MK, Völkel S (1998) Animal adaptations for tolerance and exploitation of poisonous sulfide. Annu Rev Physiol 60:33-53

Grieshaber MK, Hardewig I, Kreutzer U, Schneider A, Völkel 
$S$ (1992) Hypoxia and sulfide tolerance in some marine invertebrates. Verh Dtsch Zool Ges 85(2):55-76

Günther CP (1991) Settlement of Macoma balthica on an intertidal sandflat in the Wadden Sea. Mar Ecol Prog Ser $76: 73-79$

Jahn A, Theede $H$ (1997) Different degrees of tolerance to hydrogen sulphide in populations of Macoma balthica (Bivalvia, Tellinidae). Mar Ecol Prog Ser 154:185-196

Jahn A, Gamenick I, Theede H (1996) Physiological adaptations of Cyprideis torosa (Crustacea, Ostracoda) to hydrogen sulphide. Mar Ecol Prog Ser 142:215-223

Jahn A, Janas U, Theede H, Szaniawska A (1997) Significance of body size in sulphide detoxification in the Baltic clam Macoma balthica (Bivalvia, Tellinidae) in the Gulf of Gdansk. Mar Ecol Prog Ser 154:175-183

Janssen HH, Oeschger R (1992) The body wall of Halicryptus spinulosus (Priapulida)-ultrastructure and changes induced by hydrogen sulfide. Hydrobiologia 230:219-230

Julian D, Arp AJ (1992) Sulfide permeability in the marine invertebrate Urechis caupo. J Comp Physiol B 162:59-67

Levitt JM, Arp AJ (1991) The effects of sulfide on the anaerobic metabolism of two congeneric species of mudflat clams. Comp Biochem Physiol 98B:339-347

McDowell EM (1978) Fixation and processing. In: Trump BF, Jones RT (eds) Diagnostic electron microscopy, Vol 1. Wiley \& Sons, New York, p 113-139

Meehan BW (1985) Genetic comparison of Macoma balthica (Bivalvia, Tellinidae) from the eastern and western North Atlantic Ocean. Mar Ecol Prog Ser 22:69-76

National Research Council (1979) Hydrogen sulfide. Committee on Medical and Biological Effects of Environmental Pollutants, Subcommittee on Hydrogen Sulfide. University Park Press, Baltimore

Nicholas WL, Goodchild DJ, Stewart A (1987) The mineral composition of intracellular inclusions in nematodes from thiobiotic mangrove mud-flats. Nematologica 33:167-179

Nuß B (1984) Ultrastrukturelle und okophysiologische Untersuchungen an kristalloiden Einschlüssen der Muskeln eines sulfidtoleranten limnischen Nematoden (Tobrilus gracilis). Ver Inst Meeresforsch Bremerhaven 20:3-15

Nuß B, Trimkowski V (1984) Physikalische Mikroanalysen an kristalloiden Einschlüssen bei Tobrilus gracilis (Nematoda, Enoplida). Ver Inst Meeresforsch Bremerhaven 20:17-27

Oeschger R, Janssen HH (1991) Histological studies on Halicryptus spinulosus (Priapulida) with regard to environmental hydrogen sulfide resistance. Hydrobiologia 222:1-12

Oeschger R, Pedersen TF (1994) Influence of anoxia and hydrogen sulphide on the energy metabolism of Scrobicularia plana (da Costa) (Bivalvia). J Exp Mar Biol Ecol $184: 255-268$

Powell E (1989) Oxygen, sulfide and diffusion: why thiobiotic meiofauna must be sulfide-insensitive first order respirers. J Mar Res 47:887-932

Revsbech NP, Jorgensen BB, Blackburn TH, Cohen Y (1983) Microelectrode studies of the photosynthesis and $\mathrm{O}_{2}, \mathrm{H}_{2} \mathrm{~S}$ and $\mathrm{pH}$ profiles of a microbial mat. Limnol Oceanogr 28:1.062-1074

Editorial responsibility: Otto Kinne (Editor),

Oldendorf/Luhe, Germany
Robinson WE, Morse MP, Penney BA, Kakareka JP, Meyhöfer EU (1985) The eulamellibranch Mercenaria mercenaria (L.): a review and current data on metals accumulation and the internal transport of cadmium. In: Vernberg FJ, Thurberg FP, Calabrese A, Vernberg W (eds) Marine pollution and physiology: recent advances. Belle $W$ Baruch Library in Marine Science, Vol 13. University of South Carolina Press, Columbia, SC, p 83-106

Somero GN, Childress JJ, Anderson AE (1989) Transport, metabolism, and detoxification of hydrogen sulfide in animals from sulfide-rich environments. CRC Crit Rev Aquat Sci 1:591-614

Stauber LA (1950) The fate of india ink injected intracardially into the oyster, Ostrea virginia Gmelin. Biol Bull 98: $227-241$

Theede H (1973) Comparative studies on the influence of oxygen deficiency and hydrogen sulphide on marine bottom invertebrates. Neth J Sea Res 7:244-252

Theede $H$, Ponat A, Hiroki K, Schlieper C (1969) Studies on the resistance of marine bottom invertebrates to oxygendeficiency and hydrogen sulphide. Mar Biol 2:325-337

Theede H, Oeschger R, Jahn A (1995) Adaptive responses of marine benthic invertebrates to hydrogen sulphide. In: Eleftheriou A, Ansell AD, Smith CJ (eds) Biology and ecology of shallow coastal waters. Proc 28th Eur Mar Biol Symp, Iraklio, 1993. Olsen \& Olsen, Fredensborg, p $149-152$

Thiermann F (1998) Zur Ökologie der Nematodenfauna, besonders der dominanten Art Oncholaimus campylocer. coides (De Coninck \& Stekhoven, 1933), an sublitoralen Hydrothermalquellen der Insel Milos. Dissertation, University of Hamburg, Shaker-Verlag, Aachen, p 1-105

Thiermann $F$, Windoffer R, Giere $O$ (1994) Selected meiofauna around shallow water hydrothermal vents off Milos (Greece): ecological and ultrastructural aspects. Vie Milieu 44:215-226

Väinölä R, Varvio SL (1989) Biosystematics of Macoma balthica in northwestern Europe. In: Ryland JS, Tyler PA (eds) Reproduction, genetics and distributions of marine organisms. Proc 23rd Eur Mar Biol Symp, Swansea, 1988. Olsen \& Olsen, Fredensborg, p 309-316

Vismann B (1991) Sulfide tolerance: physiological mechanisms and ecological implications. Ophelia 34:1-27

Vopel K, Dehmlow J, Arlt G (1996) Vertical distribution of Cletocamptuns confluens (Copepoda, Harpacticoida) in relation to oxygen and sulphide microprofiles of a brackish water sulphuretum. Mar Ecol Prog Ser 141: 129-137

Windoffer R, Jahn A (1994) Morphologische und physiologische Untersuchungen zur $\mathrm{H}_{2} \mathrm{~S}$-Toleranz von Macoma balthica (Bivalvia, Tellinidae). Verh Dtsch Zool Ges 87(1): 209

Windoffer R, Jahn A (1995) Untersuchungen zur Sulfidtoleranz von Macoma balthica. Bodden 2:235-238

Würfels M. Jackwerth E (1985) Untersuchungen zur Kohlenstoffbilanz beim Aufschluß biologischer Probenmaterialien mit Salpetersäure. Fresenius Z Anal Chem 322: $354-358$

Submitted: January 1, 1999; Accepted: April 9, 1999

Proofs received from author(s): October 7,1999 